\title{
ICE CREAM CHARACTERISTIC WITH CURED EGG YOLK POWDER AS WHIPPING CREAM REPLACER
}

\author{
Citravia Agustin $^{* 1)}$, Nurliyani ${ }^{1)}$, Jamhari ${ }^{1)}$ \\ 1) Departemen Teknologi Hasil Ternak, Fakultas Peternakan, Universitas Gadjah Mada, Jl Fauna No. 03 \\ Bulaksumur, Yogyakarta, 55281, Indonesia \\ Email: nurliyani@ugm.ac.id
}

Submitted 20 August 2020; Accepted 30 November 2020

\begin{abstract}
Ice cream is a dairy product with high calorie because of fat and sugar content. Common sources of ice cream fat include butter, cream, and whipping cream. Cured egg yolk can be used as an alternative to salting eggs in a shorter time to extend the shelf life of eggs. Yolk has a high enough fat content, so it can be used to substitute fat sources in ice cream making. The purpose of this study was to determine the characteristics of ice cream with cured egg yolk powder as a substitute for whipping cream. This study used cured egg powder as a substitute for whipping cream in ice cream. This research consisted of 2 types of cured egg yolk powder (chicken and duck) and 3 levels of cured egg yolk powder substitution $(0 \%, 2 \%$, and 4\%) in whipping cream. The analysis of this research was to physical, chemical, and sensory analysis of ice cream. The results showed that the substitution of whipping cream with cured egg yolk powder had a significantly different effect $(\mathrm{P}<0.05)$ on fat content and melting point, but not significantly different on moisture, ash, protein, overrun, and sensory ice cream content. The mean moisture, ash, protein content, and ice cream overrun percentage were $58.64 \% ; 1.07 \%$; $5.30 \% ; 39.41 \%$. The average fat content and the melting rate of ice cream with 0 substitutions; $2 ; 4 \%$ cured egg yolk powder successively $9,29 \%$ fat content; $10.39 \% ; 11.13 \%$, while the melting point is $12.43 \%$ successively; $21.81 \% ; 30.43 \%$. Based on the research results, it can be concluded that the substitution of $2 \%-4 \%$ with cured egg yolk powder can increase fat content and melting point without affecting the sensory properties of ice cream, and same with ice cream's quality standard according to SNI. Duck egg of cured egg yolk powder as whipping cream replacer showed highly overrun content than chicken egg of cured egg yolk powder.
\end{abstract}

Keywords: Cured egg yolk; ice cream characteristics; whipping cream 


\section{INTRODUCTION}

Egg is a livestock product that is consumed in addition to milk and meat, but they have the disadvantage of being easily damaged physically, chemically, and microorganism activity, so that preservation and processing are required to maintain their quality. Egg drying, egg salting, egg curing are some of the methods used for preserving eggs so that they have a longer shelf life. Kaewmanee et al. (2009) stated that the brining process accelerated the curing time from 4 weeks to 4 days and produced the same sensory quality as the traditional salting method. Badola et al. (2017) stated that humectants such as salt, sugar, glycerol, and propylene glycol, can be added to the food system to develop more favorable conditions, without affecting taste and texture.

Previous research on cured egg yolk was conducted by Wang (2017) with any concentrations of $\mathrm{NaCl}$ solution and maltodextrin solution with curing time of 0 to 4 days, the result can reduce water content and water activity, but the salt content has the same level as salting with traditional methods. Furthermore, research on egg yolk powder that has been conducted by Ignario and Lannes (2007) using egg yolk flour with mini spray dryer at variations in temperature which results in no significant difference in protein content, but has very high emulsion stability. Ndife et al. (2012) stated that the drying method using the oven affects several functional properties of the egg yolk flour. After oven processing, egg yolk flour had an emulsification capacity of $74 \%$, emulsion stability of $72.40 \%$, while the decrease in emulsion ability after drying was only $1.60 \%$.
Drying cured egg yolk powder is expected to have a better shelf life than yolk with the drying process alone. Besides that, cured egg yolk powder is more simple, which is ready to be used for mixing other food ingredients.

Research on cured egg yolk with different types of chicken and duck egg was to apply to making ice cream has never been done. Therefore, cured egg yolk which is used as a substitute for whipping cream can be used an effort to diversify ice cream products which are expected to improve the quality of ice cream, both physical, chemical, and sensory.

\section{MATERIALS AND METHODS}

\section{Research Materials}

These research materials consisted of 2 types of cured egg yolk powder (chicken and duck), fresh milk, emulsifier, stabilizer, skim milk, whipping cream, and sugar. The chemical quality testing includes Kjeldahl Tablets $\left(\mathrm{K}_{2} \mathrm{SO}_{4}\right.$ and $\left.\mathrm{CuSO}_{4}\right), 4 \%$ Borax, Concentrated Sulfuric Acid, Methylene Red and $\mathrm{BCG}$ Indicators, $40 \% \mathrm{NaOH}, 0.1 \mathrm{~N}$. HCL.

\section{Research Methods}

Cured egg yolk powder preparation (Wang, 2017) with modification.

Prepare ingredients for cured egg yolk first, separate yolk and egg white, and then prepare a stainless tray for the curing mat, then add salt and sugar with ratio 50:50 and make puddle for egg yolk. Curing with a mixture of organic sea salt and granulated sugar, each yolk was completely covered with salt and then stored at room temperature for $0,2,4$, and 6 days. Preparation of cured egg yolk powder by
*Corresponding author:

Nurliyani

Email: nurliyani@ugm.ac.id

Departemen Teknologi Hasil Ternak, Fakultas Peternakan, Universitas Gadjah Mada, Jl Fauna No. 03 Bulaksumur, Yogyakarta, 55281, Indonesia
How to cite:

Agustin, C., Nurliyani., \& Jamhari. (2021). Ice cream characteristic with cured egg yolk powder as whipping cream replacer. Jurnal Ilmu dan Teknologi Hasil Ternak (JITEK), 16 (1), 11-20 
preparing the cured egg yolk to steam for $10 \mathrm{~min}$ in boiling water then shredding it, into smaller particles and then in the oven at $50^{\circ} \mathrm{C}$ for $20 \mathrm{~h}$, after that, it blended into a powder.

\section{Ice cream preparation (Adapa et al., 2000) with modification.}

Prepare ice cream ingredients: fresh milk, skim milk, whipping cream, cured egg yolk powder according to the substitution $(0 \%, 2 \%, 4 \%)$, stabilizer, and emulsifier. All ingredients are put in the pan except the emulsifier, then pasteurized until reaches a temperature of $60^{\circ} \mathrm{C}$, then emulsifier is added and then re-pasteurized until temperature of $80^{\circ} \mathrm{C}$ to $85^{\circ} \mathrm{C}$ for $30 \mathrm{~min}$. Aging processing of refrigerator in temperature at $4^{\circ} \mathrm{C}-6^{\circ} \mathrm{C}$ for $12 \mathrm{~h}$, then mixer ice cream mix on ice cream maker for $30 \mathrm{~min}$.

After $30 \mathrm{~min}$, freezing ice cream is stored overnight, then ice cream is ready for analysis.

\section{Physicochemical analysis}

Water content analysiswith oven method according to AOAC (2005), fat content analysis with soxhlet method according to Pargiyanti (2019), ash content according to AOAC (2000), protein content according to Patel et al. (2006). Overrun analysis according to Adapa et al. (2000), and melting point according to Innocente $e t$ al. (2002).

\section{Sensory analysis}

Sensory analysis according to Salem et al. (2016) with 15 Panelists includes flavor (max score 40), texture (max score 30 ), color (max score 15), and mouth melting (max score 15).

\section{Statistical analysis}

Physicochemical and sensory quality of ice cream were analyzed by Two Way analysis of variance (ANOVA) using SPSS 16 with 3 replications. Duncan Multiple Range Test (DMRT) to determine the differences between treatments.

\section{RESULTS AND DISCUSSION}

\section{Chemical Analysis}

The effect of cured egg yolk powder substitution from chicken and duck eggs on whipping cream showed no significantly on water content, ash content, and protein content but gave significantly $(\mathrm{P}<0.05)$ on ice cream fat content. The effect of cured egg yolk powder substitution from chicken and duck eggs on whipping cream on ice cream water content can be seen in Table 1, substitution of cured egg yolk powder in whipping cream gave no significant for water content.

Because cured egg yolk powder used for substitution is in the form of solid (powder) so that gave no effect on moisture content. Beside, ice cream should not contain with high water content because it will be made big frozen water when mixing of ice cream mix, and then the trapped air is low so that the ice cream development will be limited (Marshall and Arbuckle, 1997). The water content of this research is appropriate with Choi and Shin (2014) state that usually water content on ice cream is $55 \%-60 \%$. The ash content of ice cream can be seen in Table 2, the substitution of cured egg yolk powder from chicken and duck eggs in whipping cream does not give significantly different results on ash content, this is due to the curing process in making cured egg yolk. powder for 4 days with the same concentration of salt and sugar, causing no difference in the ash content of the ice cream.

Beside, the percentage of solid formulations in ice cream is also uniform. The ash content of cured ice cream is almost the same as the ash content of ice cream in general. Guven et al. (2018) reported that the ash content of ice cream varies between $0.90 \%$ to $1.16 \%$ so that there is no significant difference in the sample because the raw materials used are almost the same. The higher ash content in ice cream showed that have more inorganic ingredients are contained in the product. Egg yolk which is based cured of egg also get a role in the ash 
content of cured ice cream because egg yolk has a calcium content of $129 \mathrm{mg} / 100 \mathrm{~g}$, and phosphorus as much as $390 \mathrm{mg} / 100 \mathrm{~g}$, egg yolk also gave supplies zinc and iron respectively namely $2.30 \mathrm{mg}$ and $2.73 \mathrm{mg} /$ $100 \mathrm{~g}$ (Godbert et al., 2019).

Table 1. Water content (\%) of ice cream with cured egg yolk powder substitution in whipping cream

\begin{tabular}{lcccc}
\hline \multirow{2}{*}{ Egg type } & \multicolumn{4}{c}{ Substitutecured egg yolk powder (\%) } \\
\cline { 2 - 5 } & 0 & 2 & 4 & Mean $^{\text {ns }}$ \\
\hline Chicken & $58.20 \pm 2.29$ & $56.01 \pm 6.04$ & $56.87 \pm 1.29$ & $57.03 \pm 3.43$ \\
Duck & $58.40 \pm 0.64$ & $59.34 \pm 0.39$ & $59.48 \pm 1.14$ & $59.07 \pm 0.85$ \\
Mean $^{\text {ns }}$ & $58.30 \pm 1.51$ & $57.67 \pm 4.24$ & $58.18 \pm 1.80$ & $58.05 \pm 2.64$ \\
ns. not significant & & & &
\end{tabular}

ns: not significant

Table 2. Ash content (\%) of ice cream with cured egg yolk powder substitution in whipping cream

\begin{tabular}{lcccc}
\hline \multirow{2}{*}{ Egg type } & \multicolumn{4}{c}{ Substitutecured egg yolk powder $(\%)$} \\
\cline { 2 - 5 } & 0 & 2 & 4 & Mean $^{\text {ns }}$ \\
\hline Chicken & $1.06 \pm 0.12$ & $1.12 \pm 0.18$ & $1.13 \pm 0.05$ & $1.10 \pm 0.12$ \\
Duck & $0.97 \pm 0.09$ & $1.06 \pm 0.03$ & $1.05 \pm 0.08$ & $1.03 \pm 0.07$ \\
Mean $^{\text {ns }}$ & $1,02 \pm 0.11$ & $1.09 \pm 0.12$ & $1.09 \pm 0.08$ & $1.07 \pm 0.10$ \\
\hline
\end{tabular}

ns: not significant

Table 3. Protein content (\%) of ice cream with cured egg yolk powder substitution in whipping cream

\begin{tabular}{lcccc}
\hline \multirow{2}{*}{ Egg type } & \multicolumn{4}{c}{ Substitutecured egg yolk powder (\%) } \\
\cline { 2 - 5 } & 0 & 2 & 4 & Mean $^{\mathrm{ns}}$ \\
\hline Chicken & $4.93 \pm 0.32$ & $5.50 \pm 0.43$ & $5.49 \pm 0.30$ & $5.30 \pm 0.42$ \\
Duck & $5.42 \pm 0.36$ & $5.13 \pm 0.06$ & $5.33 \pm 0.89$ & $5.29 \pm 0.50$ \\
Mean $^{\mathrm{ns}}$ & $5.17 \pm 0.41$ & $5.32 \pm 0.34$ & $5.41 \pm 0.60$ & $5.30 \pm 0.45$ \\
\hline
\end{tabular}

ns: not significant

Table 4. Fat content (\%) of ice cream with cured egg yolk powder substitution in whipping cream

\begin{tabular}{ccccc}
\hline \multirow{2}{*}{ Egg type } & \multicolumn{4}{c}{ Substitutecured egg yolk powder $(\%)$} \\
\cline { 2 - 5 } & 0 & 2 & 4 & Mean \\
\hline Chicken & $9.35^{\mathrm{a}} \pm 0.19$ & $9.57^{\mathrm{a}} \pm 0.08$ & $10.51^{\mathrm{b}} \pm 0.06$ & $9.81^{\mathrm{x}} \pm 0.55$ \\
Duck & $9.22^{\mathrm{a}} \pm 0.15$ & $11.20^{\mathrm{c}} \pm 0.51$ & $11.74^{\mathrm{d}} \pm 0.30$ & $10.72^{\mathrm{y}} \pm 1.19$ \\
Mean $^{\text {ns }}$ & $9.29^{\mathrm{a}} \pm 0.17$ & $10.39^{\mathrm{b}} \pm 0.95$ & $11.13^{\mathrm{c}} \pm 0.70$ & $10.27 \pm 1.01$
\end{tabular}

Note: ${ }^{a, b, c, d}$ Different superscripts on the same line indicate significant differences $(\mathrm{P}<0.05)$

$x, y$ Different superscripts in the same column show significant differences $(P<0.05)$

Table 3 shows the protein content of ice cream with cured egg yolk powder substitution in whipping cream did not give significantly different results. The data analysis showed that the more substitutions were given, the protein content increased slightly, respectively $5.17 \%, 5.32 \%$, and $5.41 \%$, this was due to the presence of protein source derived from full cream milk. Beside, the ingredients used in cured egg powder are eggs, so the increase in protein content is not significant because it is only given in the percentages of $2 \%$ and $4 \%$. Tuhumury et al. ( 2016) stated that an additional concentration of Tongka Langit banana can be increase in protein content of 
ice cream, but not for protein content standard in SNI. The protein content of cured ice cream in this study was higher $(4.93 \%-5.50 \%)$ than the quality standard of ice cream according to SNI (minimum $2.7 \%$ ). Fat content in cured ice cream (Table 4) gave significantly different results ( $P$ $<0.05)$, and there was an interaction between different types of cured egg yolk from chickens and ducks with the percentage of cured egg yolk powder substitution, the more substitutions were given, further increase the fat content in ice cream. Beside, different types of eggs gave an effect on the fat content of ice cream, ice cream with cured egg yolk powder derived from chicken eggs has a lower fat content (9.81\%) compare with duck eggs (10.72\%).

This ice cream fat content still the same as SNI standards, this is explained in BSN (1995) quality ice cream should have fat content of 5\%.Rolon et al. (2017) stated that fat has a role as a structural agent that assists in the stabilization of the air phase, and creates the desired sensory quality characteristics of ice cream. Lima et al. (2016) state that ice cream that has fat content of about $9.5 \%$ can be categorized as low fat ice cream product. Fat has an important role in determining the soft and creamy texture of ice cream products, to increase viscosity, and also to increase the melting power of ice cream.

\section{Physical Analysis}

Overrun is a term for the percentage of amount air that enters the ice cream product during the freezing process (Tomer and Kumar, 2013). The results of data analysis of the cured egg yolk powder substitution level in overrun analysis showed no significant difference and there was no interaction (Table 5).

However, chicken and duck cured egg yolk powder had significant effect $(\mathrm{P}<0.05)$ on ice cream overrun, chicken cured egg yolk powder had a lower overrun (31.09\%) than duck (47.74\%). Total solids in duck egg yolk are higher than chicken eggs, according to the statement Syed et al. (2018) state that fat, sugar, Milk Solid Non Fat (MSNF), stabilizers, and emulsifiers all contribute to total solids. A good overrun of ice cream ranges from $60-100 \%$, meanwhile $12-14 \%$ fat content has $80-100 \%$ overrun (Widiantoko, 2011).

Table 5. Overrun value (\%) of ice cream with cured egg yolk powder substitution in whipping cream

\begin{tabular}{lcccc}
\hline \multirow{2}{*}{ Egg Type } & \multicolumn{4}{c}{ Substitutecured egg yolk powder $(\%)$} \\
\cline { 2 - 5 } & 0 & 2 & 4 & Mean \\
\hline Chicken & $33.84 \pm 6.76$ & $29.74 \pm 28.54$ & $29.70 \pm 9.36$ & $31.09^{\mathrm{x}} \pm 15.53$ \\
Duck & $47.21 \pm 10.82$ & $51.62 \pm 12.20$ & $44.38 \pm 9.25$ & $47.74^{\mathrm{y}} \pm 9.89$ \\
Mean $^{\text {ns }}$ & $40.53 \pm 10.89$ & $40.68 \pm 23.00$ & $37.04 \pm 11.58$ & $39.41 \pm 15.26$ \\
\hline
\end{tabular}

Note: ${ }^{\mathrm{x}, \mathrm{y}}$ Different superscripts in the same column indicate significant differences $(\mathrm{P}<0.05)$

Table 6. Melting power $(\min )$ of ice cream with cured egg yolk powder substitution in whipping cream

\begin{tabular}{lcccc}
\hline \multirow{2}{*}{ Egg Type } & \multicolumn{4}{c}{ Substitutecured egg yolk powder $(\%)$} \\
\cline { 2 - 5 } & 0 & 2 & 4 & Mean \\
\hline Chicken & $11.68^{\mathrm{a}} \pm 0.39$ & $16.05^{\mathrm{c}} \pm 0.41$ & $24.93^{\mathrm{d}} \pm 0.43$ & $17.56^{\mathrm{x}} \pm 5.86$ \\
Duck & $13.17^{\mathrm{b}} \pm 0.58$ & $27.57^{\mathrm{e}} \pm 0.50$ & $35.93^{\mathrm{f}} \pm 1.02$ & $25.56^{\mathrm{y}} \pm 9.99$ \\
Mean $^{\mathrm{ns}}$ & $12.43^{\mathrm{a}} \pm 0.92$ & $21,81^{\mathrm{b}} \pm 6.32$ & $30.43^{\mathrm{c}} \pm 6.07$ & $21.56 \pm 8.95$ \\
\hline
\end{tabular}

Note : ${ }^{a}, \mathrm{~b}, \mathrm{c}, \mathrm{d}$ Different superscripts on the same line indicate significant differences $(\mathrm{P}<0.05)$

$\mathrm{x}, \mathrm{y}$ Different superscripts in the same column show significant differences $(\mathrm{P}<0.05)$ 
The effect of cured egg yolk powder substitution from chicken and duck eggs on whipping cream for melting point of ice cream can be seen in Table 6 , showing significantly different results $(\mathrm{P}<0.05)$. The melt rate of ice cream using chicken cured egg powder melted faster, is $17.56 \mathrm{~min} / \mathrm{g}$ compared with ice cream using duck cured egg powder was $25.56 \mathrm{~min} / \mathrm{g}$. Accordance with the statement Pintor et al. (2017) state that melting power is influenced by the structural components that form the dispersed phase ice cream include ice, air, and fat.

The higher the percentage of substitution given, the higher melting point too, because egg yolk fat (phospholipid) has emulsifier also have role affects to melting point of ice cream, where the melting point increases along with addition cured egg yolk powder substitution. The melting point of duck cured egg yolk powder is higher because of fat content (phospholipid) of cured egg yolk powder also higher than chicken, so the ability to bind ice cream mix ingredientshigher than chicken cured egg yolk. Melting points also determined by room humidity, temperature difference, and wind direction will determine yield of the ice cream melting speed. The average commercial ice cream has a melting time ranging from $15-20 \mathrm{~min} / 50 \mathrm{~g}$. This is by following under the statement Nelson and Trout (1951) that the total solids in the ice cream will affect the physical properties of resistance (ice cream melting time). The duration of melting ice cream is related to the body and texture and intensity of sweetness.

\section{Sensory Quality}

The evaluated sensory quality (Table 7 ) includes flavor with a maximum value of 40, texture (maximum value 30), color (maximum value 15), and mouth melting (maximum value 15).

Table 7. Sensory quality ice cream with cured egg yolk powder substitution in whipping cream

\begin{tabular}{lcccc}
\hline Egg Type & Flavor (40) & Texture (30) & Color (15) & Mouth Melting (15) \\
\hline \multicolumn{5}{c}{ Control (substitutecured egg yolk powder 0\%) } \\
\hline Chicken & $31.73 \pm 3.73$ & $21.20 \pm 4.21^{\mathrm{a}}$ & $12.53 \pm 1.85$ & $10.33 \pm 2.72$ \\
Duck & $32.07 \pm 3.97$ & $2240 \pm 4.29^{\mathrm{ab}}$ & $12.33 \pm 1.68$ & $11.73 \pm 2.25$ \\
\hline \multicolumn{5}{c}{ Substitutecured egg yolk powder $2 \%$} \\
\hline Chicken & $31.67 \pm 5.23$ & $21.67 \pm 5.83^{\mathrm{a}}$ & $12.33 \pm 2.23$ & $11.07 \pm 3.69$ \\
Duck & $32.93 \pm 5.52$ & $25.80 \pm 3.14^{\mathrm{c}}$ & $12.87 \pm 2.80$ & $12.13 \pm 2.90$ \\
\hline \multicolumn{5}{c}{ Substitutecured egg yolk powder $4 \%$} \\
\hline Chicken & $31.27 \pm 5.87$ & $22.00 \pm 5.04^{\text {ab }}$ & $12.40 \pm 2.16$ \\
Duck & $32.47 \pm 5.33$ & $25.33 \pm 3.62^{\text {bc }}$ & $12.87 \pm 2.39$ & $11.33 \pm 2.55$ \\
Note & $: \mathrm{a}, \mathrm{b}, \mathrm{c}, \mathrm{d}$ Different superscripts in the same column show significant differences $(\mathrm{P}<0.05)$
\end{tabular}

\section{Ice cream flavor}

The results sensory test of flavor ice cream with different types of eggs and differences in the level of substitution of cured egg yolk powder showed no significant differences. Panelists gave the highest value for ice cream with chicken cured egg yolk powder substitution in the control treatment, namely 31.73 , while for ice cream with substitution of duck cured egg yolk powder with $2 \%$ substitution, 32.93 panelists preferred the flavor of ice cream that used substitution $2 \%$ cured egg yolk powder instead of ice cream with chicken cured egg yolk powder substitution. This is due to the presence of higher fat in ice cream with $2 \%$ substitution of duck cured egg yolk powder so that it affects on the quality of the flavor of the ice cream product. Ice cream fat contributes to the flavor effect of ice cream because it can add a savory taste. This is by following under the statement Sung and Goff (2010) that fat functions to provide a smooth texture, contribute to taste, and provide a synergistic effect on the additional flavors used. 


\section{Ice cream texture}

The texture assessment of cured egg yolk powder ice cream was carried out by panelists by giving a maximum score of 30 , so the more the panelists liked the ice cream product, the higher the score given. Panelists gave the highest score for cured chicken ice cream at $4 \%$ substitution, namely 22.00 , while the highest score for cured chicken ice cream at $2 \%$ substitution was 25.33 . The sugar in the composition of the ice cream is thought role in addition to providing a sweet taste, it can also improve the texture. This is by following under the statement Hartatie (2011) that sugar functions to improve texture, increase thickness, and provide a sweet taste. Stabilizer used manufacture cured egg ice cream using plain agar. This is based the statement Bahramparvar and
Tehrani (2011) stated that the purpose of using a stabilizer in ice cream is to produce smoothness in the texture of the ice cream, reduce ice crystals during storage, especially during temperature fluctuations, and prevent ice cream from melting easily.

\section{Ice cream color}

The difference in the level of substitution and the type of cured egg had no significant effect on the color of cured ice cream. Panelists gave the highest score for ice cream with chicken cured egg powder substitution, namely 12.53 for control, while the highest score for duck cured egg was 12.87 at $2 \%$ substitution. Photo of ice cream color attribute using cured egg yolk powder substitution in whipping cream is presented in Figure 1.
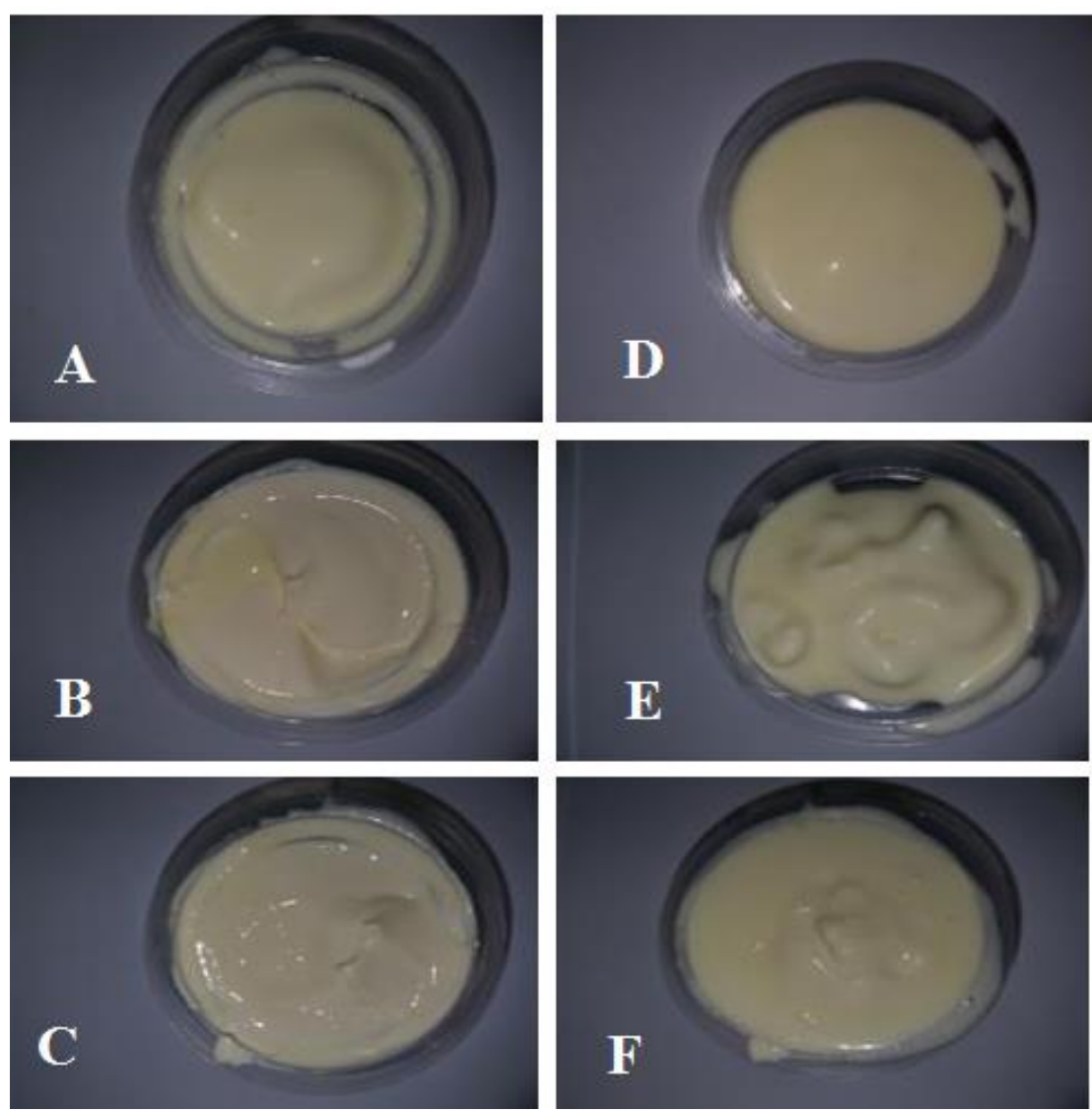

Figure 1. Chicken cured egg yolk powder'substitution (A: 0\%, B:2\%, C:4\%) and Duck cured egg yolk powder's substitution (D: 0\%, E: 2\%, F: 4\%)

Substitution of cured egg powder in ice cream as a substitute for whipping cream does not have a significant effect, this is because the percentage of cured egg powder is only $2 \%-4 \%$. This is based with the statement Winarno (2005) that natural color 
food products will change which influenced by the composition of the ingredients, efforts are made to minimize and reduce discoloration or maintain their natural color. This opinion is also supported Kartika (1998) which states that color is the most important quality attribute in the food processing industry because it can affect the level of consumer acceptance.

Mouth melting was conducted by panelists by giving a score on ice cream with a maximum value of 15 . Based on the analysis of variance, the results were not significantly different on melting mouth on ice cream. The melt rate in the mouth is based on the melting power in the mouth by the panelists. The fat content in eggs higher than milk so it can produces soft ice cream.Aime et al. (2001)state that there is a correlation between creamy mouthfeel and fat, this is also supported by Fuangpaiboon and Kijroongrojana (2017) stated that melts was decreased in the samples observed between ice creams containing fat substitutes compared to control ice creams because it was related to solids and particle size was related to the presence of fat in the ice cream. Li et al. (1997) also explain the possibility that the sample with a higher fat content formed a thicker layer than the low fat sample when it melted in the mouth.

\section{CONCLUSION}

Substitution of cured egg yolk powder $2 \%-4 \%$ can increase the fat content and melting power of ice cream without affecting the sensory quality of ice cream, and still meet the ice cream quality standards according to SNI. Duck cured egg yolk powder can produce a better ice cream overrun value than chicken cured egg yolk powder.

\section{REFERENCES}

Adapa, S., H. Dingeldein, K. A. Schmidt, and T. J. Herald. 2000. Rheological properties of ice cream mixes and frozen ice creams containing fat and fat replacers. J. Dairy Science. 83:2224-2229.

Aime, D.B., S.D. Arntfield, L.J. Malcolmson, and D. Ryland. 2001. Textural analysis of fat reduced vanilla ice cream products.Food ResearchInternational. 34:237-246.

AOAC. 2005. Official Methods of Analysis of The Association of Official Analytical Chemist. Inc, Washington, DC.

AOAC. 2000. Official Methods of Analysis. The Association of Official Analytical Chemists. 17 th edition. GaithersburgMD, USA.

Badola, R., R. R. B. Singh, N. R. Panjagari, A. K. Singh, and S. A. Hussain. 2017. Effect of selected humectants as water activity modifiers on the quality of model khoa system Effect of selected humectants as water activity modifiers on the quality of model khoa system. Indian J. DairySci. 70: 145-154.

Bahramparvar, M. and M. M. Tehrani. 2011. Application and functions of stabilizers in ice cream. Food reviews international.27: 389-407.

BSN. 1995. E s krim. Standar Nasional Indonesia. 01-3713-19.

Choi, M.J. and K.S. Shin. 2014. Studies on physical and sensory properties of premium vanilla ice cream distributed in korean market. Korean J Food Sci Anim Resour. 34 (6):757-762.

Fuangpaiboon, N. and K. Kijroongrojana. 2017. Sensorial and physical properties of coconut-milk ice creammodified with fat replacers.

Maejo International J. Sci and Tech. 11:133-147.

Godbert, R.S., N. Guyot, and Y. Nys. 2019. The golden egg: Nutritional value, bioactivities, and emerging benefits for human health. J. Nutrients. 11:1-26.

Güven, M., M. Kalender, and T. Taşpinar. 2018. Effect of using different kinds and ratios of vegetable oils on ice cream quality characteristics. Foods. $7: 2-11$ 
Hartatie, E.S. 2011. Kajian Formulasi (Bahan Baku, Bahan Pemantap) dan Metode Pembuatanterhadap Kualitas Es Krim. Gamma. 7:20-26.

Innocente, N., D. Comparin, and C. Corradini. 2002. Proteose-peptone whey fraction as emulsifier in icecream preparation. International $\mathrm{J}$. Dairy.12:69-74.

Ignário, R. M., and S. C. D. S. Lannes. 2007. Preparation of powdered egg yolk using a mini spray dryer. J. Ciencia e Tech de Alimentos. 27:729-732.

Kaewmanee, T., S. Benjakul, and W. Visessanguan. 2009. Changes in chemical composition, physical properties and microstructure of duck egg as influenced by salting. Food Chem.112:560-569..

Kartika. 1998. Petunjuk Evaluasi Produksi Industri Hasil Pertanian. UGM. Yogyakarta.

Li, Z., R. Marshall, H. Heymann, and L. Fernando. 1997. Effect of milk fat content on flavor perception of vanilla ice cream. J. Dairy Sci. 80:31333141.

Lima, J. G. de, T. C. Brito-Oliveira, and S. C. de Pinho. 2016. characterization and evaluation of sensory acceptability of ice creams incorporated with beta-carotene encapsulated in solid lipid microparticles. J. Food Sci and Tech. 36:664-671.

Marshall, R. T. and W. Arbuckle. 1997. Ice Cream. 5th ed. InternationalThomson, New York.

Ndife, J., Udobi, C. Ejikeme, and N. Aamaechi. 2012. Effect of Oven drying on the nutritional properties of whole egg and its components.

African J. Food Sci. 4(5): 254-257

Nelson, J.A. and G. Trout. 1951. Judging Dairy Products. In: The Oisen Publishing Company, Wisconsin.

Pargiyanti. 2019. Optimasi waktu ekstraksi lemak dengan metode soxhlet menggunakan perangkat alat mikro soxhlet. Indonesian J. Laboratory.
1:29-35.

Patel, M. R., R. J. Baer, and M. R. Acharya. 2006. Increasing the protein content of ice cream. J. Dairy Sci. 89:14001406.

Pintor, A., H. B. Escalona-Buendía, and A. Totosaus. 2017. Effect of inulin on melting and textural properties of lowfat and sugarreduced ice cream: Optimization via a response surface methodology. International J. Food Reseacrh. 24:1728-1734.

Rolon, M.L., A.J . Bakke, J.N. Coupland, J.E. Hayes, and F.R. Roberts. 2017. Effect of fat content on the physical properties and consumer acceptability of vanilla ice cream. J. Dairy Sci. 100:5217-5227.

Salem, S. A., E. M. Hamad, and I. S. Ashoush. 2016. Effect of partial fat replacement by whey protein, oat, wheat germ and modified starch on sensory properties, viscosity and antioxidant activity of reduced fat ice Sathe, S. K., S. S. Deshpande, and D. K. Salunkhe. 1982. Functional properties of winged bean [psophocarpus tetragonolobus (1.) proteins. J. Food Sci. 47:503-509.

Sung, K.K, and H.D Goff. 2010. Effect of solid fat content on structure in ice creams containing palm kernel oil and high-oleic sunflower oil. J. Food Sci. 75:4-9.

Syed, Q.A, S. Anwar, R. Shukat, and T. Zahoor 2018. Effects of different ingredients on texture of ice cream. J. Nutritional Health \& Food Eng. 8:422-435.

Tomer, V. and A. Kumar. 2013. Development of high protein icecream using milk protein concentrate. IOSR J. Environmental Sci, Toxicology and Food Tech 6:71-74.

Tuhumury, H. C. D., S.J. Nendissa, and M. Rumra. 2016. Kajian sifat fisikokimia dan organoleptik es krim pisang tongka langit. Agritekno, J.Tek Pertanian. 5:46.

Wang, T. H. 2017. Salting yolks directly 
using fresh duck egg yolks with salt and maltodextrin. J. Poultry Sci. 54:97-102.

Widiantoko, R. K. 2014. Pembuatan es krim tempe - jahe ( kajian proporsi bahan dan penstabil terhadap sifat fisik, kimia dan organoleptik ). Jurnal Pangan dan Agroindustri. 2:54-66.

Winarno. 2005. Kimia Pangan dan Gizi.Gramedia Pustaka Utama, Jakarta. 